Sobchuk A. V. Taras Shevchenko National University of Kyiv, Kyiv

Barabash O. V., Musienko A. P. State University of Telecommunications, Kyiv

\title{
ASSESSMENT METHODS OF FUNCTIONAL STABILITY OF WIRELESS SENSOR NETWORKS
}

The paper examines the basic requirements and criteria for functionally stable complex systems, including for wireless sensor networks. The mathematical model of a functionally stable wireless sensor network based on the network connectivity, useful bandwidth of its elements, reliability of data transmission, and power consumption during the transmission process is improved. The selected criteria of functional stability and the system of permissible restrictions for wireless sensor networks are substantiated.

Keywords: wireless sensor network, functional stability, optimization, mathematical model.

Собчук А.В. КНУ ім. Тараса Шевченка, Київ

Барабаш О.В., Мусієнко А.П. Державний університет телекомунікаиій, Київ

\section{МЕТОДИ ОЦІККИ ФУНКЦІОНАЛЬНО СТІЙКОЇ БЕЗДРОТОВОЇ СЕНСОРНОЇ МЕРЕЖI}

У роботі досліджено основні вимоги та критерії для функиіонально стійких складних систем, в тому числі для бездротових сенсорних мереж. Удосконалено математичну модель функиіонально стійкої бездротової сенсорної мережі, в основі якої лежать показники зв'язності мережі, корисну пропускну здатність ї̈ елементів, надійність передачі даних, енерговитрат при здійсненні процесу передачі. Обтрунтовано обрані критерії функціональної стійкості, а також систему допустимих обмежень для бездротових сенсорних мереж. Важливим напрямком подальших досліджень теорії функиіональної стійкості БСМ є інтеграція нових розробок технологій бездротової передачі інформачї та завдань їх впровадження, які виникають, включно з необхідністю дотримання стандартів конфідениійності, иілісності та доступності даних, які генеруються даним типом мереж, їх оновленням, синхронізацією часу обробки, перенавантаженням мережі, енергозбереженням та стандартизачією, а також вдосконаленням математичного апарату наявних обмежень, концептуальних та технічних змін. У роботі наведено иільову функиію, щчо дозволяе створити оптимальну структуру БСМ, однак в залежності від застосування та діючих дестабілізуючих факторах необхідно виділити основні $i$ другорядні критерії функиіонування системи. Слід враховувати, що оптимальну структуру БСМ можна розглядати незалежно на кожному з рівнів функиіонування системи, однак неможливість перерозподілу ресурсів (енергетичних, обчислювальних, інформачійних $і$ т.д.) системи обмежує можливість формування функиіонально стійкого управління нею в иілому або ж на умовних рівнях ї̈ функиіонування.

Ключові слова: бездротова сенсорна мережа, функиіональна стійкість, оптимізація, математична модель.

Собчук А.В. КНУ им. Тараса Шевченко, Киев

Барабаш О.В., Мусиенко А.П. Государственный университет телекоммуникаиий, Киев

\section{МЕТОДЫ ОЦЕНКИ ФУНКЦИОНАЛЬНОЙ УСТОЙЧИВОСТИ БЕСПРОВОДНОЙ СЕНСОРНОЙ СЕТИ}

В работе исследовано основные требования и критерии для функционально устойчивых сложных систем, в том числе для беспроводных сенсорных сетей. Усовершенствована математическая модель функционально устойчивой беспроводной сенсорной сети, в основании которой лежат показатели связанности сети, полезной пропускной способности ее элементов, надежности передачи данных, энергетических затрат при осуществлении процесса передачи.

(C) Собчук А.В., Барабаш О.В., Мусієнко А.П. 2019 
Обоснованно выбранные критерии функичиональной устойчивости, а также систему допустимых ограничений для беспроводных сенсорных сетей.

Ключевые слова: беспроводная сенсорная сеть, функциональная устойчивость, оптимизация, математическая модель.

\section{Introduction.}

The Wireless Sensor Network (WSN) is a distributed self-organizing system of autonomous sensors in operation, as well as wireless communication channels. By retransmitting messages between elements of the network it is possible to transmit data at a fairly large distance, with insignificant power consumption. In order to ensure the continuous and reliable functioning of the WSN in stand-alone mode for long periods of operation, it is necessary to provide a system of properties of functional stability. In this case, the system will be insensitive to external and internal destabilizing factors, which will allow to perform basic functions of the system [1].

The development of WSN is one of the most important areas covered in the global and European research environments, wireless technology for the transfer of information and technology of the Internet of Things is considered as strategic research objectives in international programs such as FP7 and Horizon 2020. These programs cover areas such as "smart" logistic, health care, climate change control, etc. [2].

Scientific researches in the field of WSN cover a wide range of issues:

- Distributed data processing;

- Communication / standardization of communication protocols;

- Time to synchronize the components of the sensor network;

- Distribution and automatic localization of components of WSN;

- Time of life / energy intensity / energy saving WSN;

- Reliability, quality of service (QoS) and stability of WSN functioning;

- Safety and monitoring of WSN work;

- Legal and ethical aspects related to the integration and application of sensor networks.

The research of existing scientifically grounded approaches to increasing the functional stability of the WSN has shown that at present there is no comprehensive mathematical model of WSN that would meet the existing criteria of functional stability and take into account the existing system of constraints at all levels of the model of system functioning.

\section{Analysis of literary data and problem statement}

The analysis of scientific works relating to the existing theory of functional stability of complex systems and WSN in particular testifies that in his works Professor Mashkov O.A. [6] formulated the property of functional stability and developed a general strategy for its provision for complex technical systems.

Currently, followers of the scientific school of functional stability Barabash O.V., Kravchenko Yu.V., Kononov O. A., Nedilko S. M., Obidin D. M., Musienko A. P. and others contributed to the development of the conceptual apparatus and solved the problem of providing functional stability for specific technical systems, which is given in the papers [7, 8]. Thus, the approach proposed in O.V. Barabash works, in particular [7], suggests the use of indicators and criteria for building sustainable data transmission systems based on the estimates of the connectivity of graphs in the network. In the work of Yu.V. Kravchenko [8] a slightly different approach is proposed to determine and provide functional stability for complex technical systems, based on solving an optimization problem using matroid structures.

A large community of scientists is engaged in scientific research, which is related to individual properties of WSN, implementation of their conceptual, system-technical and organizationaltechnical characteristics, in particular: Schmid S., Lewis P., Ivanova I.A., Zelenin A. N., Vlasova V. A., Efremov S. G., Galenyuk I. B., Yevtukh G. S., Karpinsky V. M., Moon I., Park P., Wong H., Wu N., D. Culler, X Mufta, R. Odarchenko, D. Ragozin, S. Raiba, S. Toluepa, R. Shorey, L. Shu and others.

Therefore, an important direction in the research of the theory of functional stability of the WSN is the integration of new developments in the technology of wireless transmission of 
information and the tasks of their implementation, which arise, including the need to comply with the standards of confidentiality, integrity and availability of data generated by this type of network, their upgrade, synchronization processing time, overload network, energy saving and standardization, as well as the development of the mathematical apparatus of existing constraints, conceptual and technical changes.

Studies have shown that the known properties of complex technical systems, which include WSN, such as stability, reliability, durability, fault-tolerance characterize the functioning of systems under the influence of failures and damages. But they do not allow to fully describe the processes of functioning in conditions of internal and external destabilizing factors. It is therefore advisable to provide the investigated system with a new feature of complex technical systems - functional stability [3].

The theory of functional stability proposes to consider the freelance states of the system, caused by failures, as permissible, and to form for them adequate (functionally stable) control, aimed at overcoming the consequences of failures and support the implementation of the main functions of the system. This ensures redistribution of system resources to achieve the main goal, even in the event of failure. The basic condition for the provision of this property is the possibility of redistribution of available resources within the system [4]. Therefore, to date, the main task is to develop and apply the properties of functional stability in the context of WSN, in the face of new problems and problems that can not be considered and solved entirely by other properties of complex technical systems in the presence of destabilizing factors. At the same time, more detailed study in such situations requires issues related to: confidentiality (level of security of the transmission channel), integrity (avoiding the change or loss of individual packages) and the availability of data (obtaining information for a time that does not exceed the specified), overloading of the network, its self-organization, updating of data, synchronization of processing time, energy saving, standardization, etc. [5].

\section{The purpose and objectives of the study}

The purpose of the article is to analyze the existing properties of WSN and to improve the mathematical model of functionally stable WSN, which is based on useful bandwidth, reliability and energy costs in data transmission.

To achieve this goal, the following tasks are solved:

- formation of a system of limitations of the objective function, in order to create the optimal structure of the WSN, which meets all the necessary conditions and criteria of functional stability;

- to identify the main and secondary criteria for the functioning of the WSN;

- to solve the overall problem of synthesis of the WSN structure and to find the values of the global minimum and maximum for a specific objective function.

\subsection{Determination of the property of functional stability among other properties of complex systems}

The architecture of almost any WSN can be described using a reference OSI model. In the most common case, such architecture includes five levels: application, transport, network layer, data rate (channel) and physical layer [9]. Each of these levels of the model has its own intended purpose and in general is responsible for: organizing the operating modes of the WSN (channel, application), managing power transfer (physical, network, application), reducing the amount of data (network, transport, application), network nodes management (applied) [10].

Therefore, the normal functioning of the network depends on the functioning of each of the levels of the OSI model. To implement the description of access to information, the notion of the generalized functional architecture of the sensor network is introduced. This architecture defines the functional components of the network and the connections between them, the division of responsibilities to support the main functions of the network [11].

It should be noted that there is a certain difference between such concepts as stability of functioning and functional stability of the system. Barabash O.V. first proved the general difference between these concepts (Fig. 1) and formalized the functional stability in the system of properties of complex technical systems [12]. 


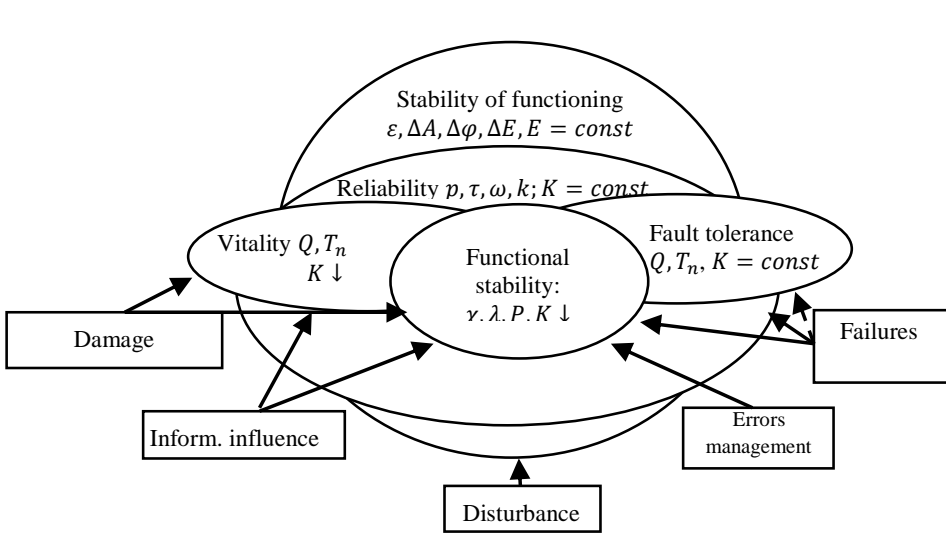

Fig. 1. Comparative characteristics of properties of complex systems and destabilizing factors of influence
Functional sustainability indicators reflect the outcome of a strategy for providing it through redistribution of existing redundancy or resources in emergency situations and directly affect system construction, while system failures are considered acceptable and require adequate (functionally sustainable) management aimed at rejecting them. Failure and support for the execution of major functions.

\subsection{Graphic representation of the wireless sensor network}

The impossibility of redistribution of resources (energy, computing, information, etc.) of the system limits the possibility of forming a functionally stable management of it. The complex use of resources and the provision of functional stability of systems is limited by the conditions of stability of the dynamic system, its management and the criterion of visibility of Kalman [13].

Graphic criterion of functional stability can be described as [13]:

where:

$$
G=\{V, R\}
$$

$V$ - set of vertices of the graph $V=\left\{x_{i}, y_{j}, u_{k}\right\}, i=[1, \ldots, n], j=[1, \ldots, l], k=[1, \ldots, m]$, which corresponds to the components of the vectors $X, Y, U$;

$R$ — set of edges of the graph $R=\left\{\left(X_{i}, Y_{j}\right),\left(Y_{j}, U_{k}\right),\left(U_{k}, X_{i}\right)\right\}$, which corresponds to the presence of a functional connection between the components of the network;

$X(t)$ - $i$-measurable vector of system state; $Y(t)$ - $l$-dimensional vector of measurements; $U(t)-k$-dimensional vector of control.

The dynamic system will be functionally stable in case of failure if there is such a path $\mathrm{A}=$ $\left(X_{i}, \ldots, U_{i}\right)$, which includes all components of vectors $X$ i $U$.

The structure of the WSN bonds is described using the adjacency matrix:

$$
S=\left\|s_{i j}\right\|, s_{i j}=\left\{1, \text { at } e_{i j} \in E ; 0, \text { at } e_{i j} \notin E .\right.
$$

where: $e_{i j}$ - communication line between $i$ and $j$ network sensors.

The basic requirement for functional stability can be formulated as [14]:

1. Ensure the performance of all network nodes:

where: $V=\left\{v_{i}\right\}$ - set of network elements;

$$
\forall v_{i} \in V \Leftarrow \omega_{i}(\tau)=1, \tau \in[0, t),
$$

$\omega(\tau)$ - a boolean function that takes value 1 if the WSN element is in an operational state and 0 is otherwise;

$\tau, t$ - current operating time

2. Provide information to the WSN base station on main and backup routes:

$$
\forall v_{i}, v_{j} \Leftarrow \exists v_{j} \in G_{i}, i, j=1,2, \ldots, n,
$$

where: $G_{i}$ - set of achievable vertices graph from the vertex $V_{s}$;

$n$ - Number of elements of the WSN.

\subsection{Functional stability criteria}

Therefore, the criteria for functional stability are defined as [7]:

1. Structural criterion. The WSN will be functionally stable if the number of vertex connectivity and the number of edge connectivity satisfy the requirements: 


$$
X(G) \geq 2 \cup \lambda(G) \geq 2 .
$$

where: $X(G)$ - this is the smallest number of vertices, the removal of which, together with the incident ones, leads to an unconnected or single-span graph;

$\lambda(G)$ - this is the smallest number of edges, the removal of which leads to an unconnected graph.

2. Probabilistic criterion. The structure of the WSN will be functionally stable if the probability of the connection between each pair of vertices is not less than given:

$$
P_{i j}(t) \geq P_{i j}^{\text {const }}, i \neq j, i, j=1,2, \ldots, n,
$$

where: $P_{i j}(t)$ - this is the probability that the message from the site $i$ the node $j$ will be transmitted in time not more than $t$.

$n$ - number of vertices of the graph $G(V, E)$.

Consider in more detail the structural criterion of functional stability of the WSN. To ensure the vertex and edge connectivity of the network elements, the necessary condition is to provide certain technical characteristics of the network with destabilizing factors.

As one of the main criterion of vertex connectivity, one can consider providing power saving function with the elements of the WSN. A study [15] shows that there is a direct relationship between energy consumption and the total number of working units. Accordingly, it is necessary to reduce and optimize overall energy consumption.

In the general case, the function minimizing the sum of the total energy consumed in all nodes can be written as [1]:

$$
\operatorname{MIN} \sum_{i \in N} e_{i 0}-\sum_{i \in N, i \neq n} E_{i(e t)} \text {, }
$$

where: $e_{i 0}$ - initial energy indicator of the node $i$,for all $i \in N\left(e_{i 0}>0\right)$;

$E_{i t}$ - energy indicator node $i$ in the period of time $t$, for all $i \in N, t \in T$;

$i, j-$ network node indexes.

As a criterion for edge connectivity, we can consider the reliability of data transmission, which is expressed as the ratio of the number of lost and received packets, and the useful bandwidth for the working elements of the network.

When information is transferred between the WSN nodes to the base station, some of them act as transit nodes. Each of the WSN transit nodes contains a buffer to store some limited data received, to be transmitted to the next node of the route.

The route as a whole is a multiphase system of mass service, formed by a sequence of models of individual plots.

The probability of loss of the data packet during transmission between the nodes of the WSN may be defined as [16]:

where: $p_{i}$ can be defined as:

$$
p=1-\prod_{i=1}^{w}\left(1-p_{i}\right),
$$

$$
p_{i}=\frac{1-p}{1-p^{\frac{2}{C_{a}^{2}+C_{s}^{2}} \cdot n_{b}+1}} \cdot p^{\frac{2}{C_{a}^{2}+C_{s}^{2}} \cdot n_{b}},
$$

where: $C_{a}^{2}$ and $C_{s}^{2}$ quadratic coefficients of variation of the input data flow distributions and maintenance time for $i$ node; $n_{b}$ - buffer size; $p$ workload $i$ node.

The route of delivery of data packets in the WSN from the data source to the base station $D$ may have several routes $w$ of the transmission, which are formed by separate nodes of the network.

The optimization task in the transmission of data with redundancy is formulated in the following way. Suppose there are $N$ independent routes, each of which is described by a vector $\left(p_{i}, E_{i}, T_{i}\right)$, which is required to send a message consisting of $k$ packages. In this case, the transfer error $P_{e}(k, N)$ should not exceed the set value $p$. To do this, you need to find the number of packets to be transmitted on each route, that is to find the set $\left(n_{1}, \ldots, n_{N}\right),\left(n_{i} \in N\right)$, for which the following restrictions will be met: 
1. Number of data transfer errors:

$$
P_{e}(k, N)=P\left(n_{1}, n_{2}, \ldots, n_{N}\right) \leq p,
$$

where the value of the function $P$ depends on the selected data transfer algorithm;

2. Total power consumption for data transmission:

3. Total sending time:

$$
E\left(n_{1}, n_{2}, \ldots, n_{N}\right)=\sum_{i=1}^{N} E_{i} \cdot n_{i} \rightarrow \min _{i} .
$$

$$
T\left(n_{1}, n_{2}, \ldots, n_{N}\right)=\left\{T_{i}+r \cdot n_{i}\right\} \rightarrow \min
$$

The probabilistic criterion suggests that the probability of the coupling of each pair of vertices must be not less than the given value to provide the property of the functional stability of the WSN. Accordingly, having considered the basic requirements, the above restrictions and criteria of functional stability, we can formulate the problem of synthesizing the structure of the WSN as follows:

$$
\begin{aligned}
& F_{W S N}=\left\{P_{i j}, C_{\text {max }}, Z_{\text {max }}, E_{\text {min }}\right\}, i, j=1, \ldots, N, i \neq j ; \\
& \forall \pi_{i j} P_{i j} \geq P_{\text {const }}, \\
& \quad C_{i j} \leq C_{\text {max }}, \\
& P\left(n_{1}, n_{2}, \ldots, n_{N}\right) \leq p, \\
& \left\{T_{i}+r \cdot n_{i}\right\} \rightarrow \min \leq T_{\text {const }}, \\
& \sum_{i=1}^{N} E_{i(t)} \cdot n_{i} \rightarrow \min , E_{i(t)} \geq 0 .
\end{aligned}
$$

where: $N$ - number of elements of the WSN;

$F_{W S N}$ - target function of WSN;

$P_{i j}$ - the probability of coupling between the couple $(i, j)$ network sensors;

$C_{\text {max }}$ - the useful capacity of the WSN elements;

$Z_{\text {max }}$ - the reliability of the data transmission between the elements of the network;

$E_{\text {min }}$ - energy costs for conversion, processing and data transmission;

$\pi_{i j}$ - possible routes of data transfer between the $i$-th and $j$-th elements of the WSN;

$T_{\text {const }}$ - the allowed delay time of the message;

$E_{i(t)}$ - the energy charge of the $i$-th node at time $t$.

Expression (1) describes the optimization criterion: the value of the functional stability of the WSN structure. As a measure of functional stability, a generic metric is selected to characterize the likelihood of network element connectivity, useful WSN bandwidth, data transmission reliability, and energy costs for conversion, processing, and data transmission.

After solving this optimization problem, we will find the optimal structure of the WSN, which consists of $N$ sensors and will satisfy the optimization criterion (1) and constraint (2 - 6).

The above objective function allows to create the optimal structure of WSN, however, depending on the application and the current destabilizing factors, it is necessary to distinguish the basic and secondary criteria. It is necessary to consider the optimal structure of WSN can be considered independently at each of the levels of functioning of the system.

The formulated problem $(1-6)$ will be considered as the general task of synthesis of the structure of the sensor network.

\subsection{Optimization problem}

As an example, let's solve a special case of a formulated synthesis problem and find global extrema for the objective function (function function) of the form:

$$
f\left(x_{1}, \ldots, x_{n}\right)=\sum_{i=0}^{n} x_{i}^{2} \text {, on the set of values } \sum_{i=1}^{n} x_{i}^{4} \leq 1,
$$

Restriction system:

$$
\left\{\begin{array}{l}
x_{1}^{2}+\cdots+x_{n}^{2} \rightarrow \text { extr } \\
x_{1}^{4}+\cdots+x_{n}^{4}-1 \leq 0
\end{array}\right.
$$


Let's compose the Lagrange function and compute its partial derivatives:

$$
\begin{gathered}
(x, \lambda)=\lambda_{0}\left(x_{1}^{2}+\cdots+x_{n}^{2}\right)+\lambda_{1}\left(x_{1}^{4}+\cdots+x_{n}^{4}-1\right) \\
\frac{\partial L(x, \lambda)}{\partial x_{i}}=2 \lambda_{0} x_{i}+4 \lambda_{1} x_{i}^{3}, \quad i=1, \ldots, n .
\end{gathered}
$$

Let us write out the necessary condition for the extremum:

$$
\left\{\begin{array}{c}
2 \lambda_{0} x_{i}+4 \lambda_{1} x_{i}^{3}=0, \quad i=1, \ldots, n \\
\lambda_{1}\left(x_{1}^{4}+\cdots+x_{n-1}^{4}-1\right)=0 .
\end{array}\right.
$$

a) Consider the case $\lambda_{0}=0$ :

$$
\left\{\begin{array}{c}
4 \lambda_{1} x_{i}^{3}=0, \quad i=1, \ldots, n \\
\lambda_{1}\left(x_{1}^{4}+\cdots+x_{n-1}^{4}-1\right)=0 .
\end{array}\right.
$$

Obviously, this system is only resolved at $\lambda_{1}=0$, and there are no suspected extremal points.

b) Consider now the case when $\lambda_{0}=2$ :

$$
\left\{\begin{array}{c}
4 x_{i}+4 \lambda_{1} x_{i}^{3}=0, \quad i=1, \ldots, n, \\
\lambda_{1}\left(x_{1}^{4}+\cdots+x_{n-1}^{4}-1\right)=0 .
\end{array}\right.
$$

The last equation of the system splits into two equations:

$$
\lambda_{1}=0 \text { i } x_{1}^{4}+\cdots+x_{n-1}^{4}=1 .
$$

If $\lambda_{1}=0$, then $x_{1}=\ldots=x_{n}=0$. We get one point $(0, \ldots, 0)$. In it, the target function takes a null value. As at all other points the objective function is positive, the global point is reached at the found point.

Now let $\lambda_{1} \neq 0$. Then our system is equivalent to:

$$
\left\{\begin{array}{c}
x_{i}\left(1+\lambda_{1} x_{i}^{2}\right)=0, \quad i=1, \ldots, n, \\
\left(x_{1}^{4}+\cdots+x_{n-1}^{4}\right)=1 .
\end{array}\right.
$$

If $\lambda_{1} \geq 0$, then from the first $\mathrm{n}$ equations of the system we obtain equations $x_{1}=0, \ldots, x_{n}=$ 0 which contradict the last equation. If, however $\lambda_{1}<0$, then each of the first $n$ equations has three solutions for $x_{i}: x_{i}=0, x_{i}= \pm \sqrt{-1 / \lambda_{1}}$.

Denote by $I$ the set of indices $i \epsilon\{1, \ldots, n\}$, for which $x_{i}= \pm \sqrt{-1 / \lambda_{1}}$, and put it $k=|I|$ then:

$$
x_{1}^{4}+\cdots+x_{n}^{4}=\sum_{i \in I} x_{i}^{4}+\sum_{i \notin I} x_{i}^{4}=\sum_{i \in I} \frac{1}{\lambda_{1}^{2}}=\frac{k}{\lambda_{1}^{2}}=1,
$$

whence it follows that $\lambda_{1}=-\sqrt{k}$, and accordingly:

$$
x_{i}= \pm \sqrt[4]{1 / k}, i \in I, x_{i}=0, i \notin I
$$

All points with such coordinates are suspected of extreme. In each of these, the objective function takes on the value:

$$
\sum_{i=1}^{n} x_{i}^{2}=\sum_{i \in I} x_{i}^{2}=\frac{k}{\sqrt{k}}=\sqrt{k} .
$$

This value will be maximal at $k=n$, that is, when all coordinates of the suspects at the extremum of the point is non-zero. It follows that the objective function $f$ reaches a global maximum at the points $\mathrm{x}$ at which all the coordinates $x_{i}$ are equal $\pm \sqrt[4]{1 / n}$. In this case $f_{\max }=\sqrt{n}$.

Consider the other suspected extrema points. Since $\lambda_{1}=-\sqrt{k}<0$, then they are subject to the agreement of signs or a local maximum or no extremum. Let us check for these points the conditions of the second order. To do this, we calculate partial derivatives:

$$
\frac{\partial^{2} L(x, \lambda)}{\partial x_{i}^{2}}=2 \lambda_{0}+12 \lambda_{1} x_{i}^{2}, \quad \frac{\partial^{2} L(x, \lambda)}{\partial x_{i} \partial x_{j}}=0, i \neq j
$$




$$
L_{x x}^{\prime \prime}(a, \lambda) d x^{2}=\sum_{i=1}^{n}\left(4-12 \sqrt{k} a_{i}^{2}\right) d x_{i}^{2}=4 \sum_{i \notin I} d x_{i}^{2}-8 \sum_{i \in I} d x_{i}^{2} .
$$

Let put $\varphi(x)=x_{1}^{4}+\cdots+x_{n}^{4}-1$ and write out the condition $\varphi^{\prime}(a) d x=0$ :

$$
\varphi^{\prime}(a) d x=\sum_{i=1}^{n} 4 a_{i}^{2} d x_{i}=4 \sum_{i \in I} a_{i}^{3} d x_{i}=0 .
$$

Consider a vector $d x$ whose coordinates are zero except one coordinate $d x_{i}$, that matches any index $i \notin I$. The following conditions will be fulfilled for him:

$$
\varphi^{\prime}(a) d x=0, \quad L_{x x}^{\prime \prime}(a, \lambda) d x^{2}>0 .
$$

Assertion 1. Let there be a point $a \in \Omega$ that satisfies the Lagrange principle, by which:

$$
I=\left\{i \in \overline{1, m+k} \mid \varphi_{i}(a)=0\right\} .
$$

If derivatives $\varphi_{i}^{\prime}(a), i \in I$ are linearly independent and there exists a vector $d x$ for which the following condition holds:

$$
\varphi_{i}^{\prime}(a) d x=0, \quad i \in I, \quad L_{x x}^{\prime \prime}(a, \lambda) d x^{2}<0(>0),
$$

then there is no local minimum (maximum) at point $a$.

According to statement 1 we have: the global minimum is reached at the point $x=0$ and is equal to 0 , the global maximum is reached at the points whose coordinates are as follows: $\pm \sqrt[4]{1 / n}$, and is equal to $\sqrt{n}$. There are no other extremes.

\section{Discussion of results of research of methods of estimation of functional stability of wireless sensor networks}

Analysis of scientific works related to the existing theory of functional stability of complex systems and WSN in particular. An important area of research on the theory of functional stability of WSN is the integration of new developments in wireless technology and the tasks of their implementation. Depending on the application and the destabilizing factors involved, the main and minor criteria should be distinguished.

\section{Conclusions}

This paper analyzes the existing properties of WSN, in particular, the mathematical model of functionally stable WSN, which is based on the probability of connectivity between network elements, useful bandwidth, reliability and energy consumption in data transmission. The formulated restriction system and the objective function allow to create the optimal structure of the WSN, and meets all the necessary conditions and criteria of functional stability. However, depending on the application and the destabilizing factors involved, it is necessary to distinguish between basic and minor criteria. It is necessary to consider the optimal structure of WSN can be considered independently at each of the levels of functioning of the system. The general problem of synthesis of the WSN structure is solved and the values of the global minimum and maximum for the determined objective function are found.

\section{References}

1. Sobchuk A.V., Koval M.O., Kravchenko Yu.V., and Barabash O.V. "Mathematical model of functionally stable wireless sensor network." Scientific periodical edition "Systems of control, navigation and communication», Poltava: PNTU, 6 (46) (2017): 122-126 Print.

2. "7th International Conference on Wireless Sensor Networks" (WSN'18) [Resource] Resource Access Mode: https://fedcsis.org/2018/wsn.

3. Kravchenko Yu. V., and Mikush S. A. "Current state and ways of development of the theory of functional stability. Collection of scientific works of the Institute of Modeling Problems in Power Engineering them. G. E. Pukhov, Issue 69 (2013): 40-48. - Access mode: http://nbuv.gov.ua/UJRN/znpipm_2013_69_7.

4. Mashkov O. V. Kononov O. A., and Pekarev D. V. "Methods of construction of functionally stock complex dynamic systems." HISTORY OF ZHDTU (2006): 93-103 Print. 
5. Shabana K., Nigar F., and Khan F. "Security issues and attacks in Wireless Sensor Networks." International Journal of Advanced Research in Computer Science and Electronics Engineering (2016): 81-87. Print.

6. Mashkov O. A., and Barabash O.V. "Topological criteria and indicators of functional stability of complex hierarchical systems." Modeling and Information Technologies: Collection of Scientific Papers. - K.: IPEM NAS of Ukraine, 25 (2003): 29 - 35. Print.

7. Barabash O.V. The construction of functionally stable distributed information systems, NAOU, 2004. Print.

8. Kravchenko Yu.V., and Barabash O.V. "Functional stability - the property of complex technical systems." Collection of scientific works of NAOU 40 (2002): 225-229. Print.

9. Alkhatib A. Baicher G. "Wireless Sensor Network Architecture." International Conference on Computer Networks and Communication Systems 35 (2012): 11-15. Print.

10. Kovalenko, I.G. "Methods of increasing the duration of operation of wireless sensor networks with excessive number of nodes." Telecommunication and information technologies 1 (2014): 44-54. Print.

11. Snizhko Y. M., and Petrovnin D. I. "Model analysis of dynamic free durables of sensor networks." Scientific and technical collection of the NMU (2010): 125-133. Print.

12. Obidin D. N., Zadkov E. V., and Hazov A. S. "Analysis of criteria and indicators of the efficiency of complex technical systems in trajectory problems of flight dynamics." Control systems, navigation and communications 1 (2014): 76-80. - Access mode: http://nbuv.gov.ua/UJRN/suntz_2014_1_18.

13. Mashkov OA, Samchishin O. V. "Modern problems of the development of the theory of functionally stable complex control systems." Modeling and Information Technologies: Coll. sciences Ave, IPEM them. G. E. Puhov NAS of Ukraine 52 (2009): 136 - 145. Print.

14. Barabash O.V., Kireyenko V.V. "Selection of indicators and criteria for assessing the functional stability of the airborne intelligence system and alert at the stage of its construction." Modern information technologies in the field of security and defense 3 (2013): 5-7. - Access mode: http://nbuv.gov.ua/UJRN/sitsbo_2013_3_3.

15. Junaid Ahmed Khan, Hassaan Khaliq Qureshi, and Adnan Iqbal. Energy management in Wireless Sensor Networks: A survey [Electronic resource] Computers \& Electrical Engineering. (2015): Access mode: https://hal.archives-ouvertes.fr/hal-01283728/document.

16. Kirichek RV Development and research of a complex of models and methods for flying sensor networks: author's abstract. dis for obtaining sciences. A thesis for the science degree of candidate (doctor of philosophy) in speciality 05.12.13 "Systems, networks and telecommunication devices", 2018. Print.

\section{Authors of the article}

Sobchuk Andrii Valentynovych - postgraduate student, Networks and Internet technology Department. Phone: +38 (093) 74431 52. E-mail: anri.sobchuk@gmail.com.

Barabash Oleg Volodymyrovych - Doctor of Technical Sciences, Professor, Head of Higher Mathematics Department. Phone: +38(095)8702490. E-mail: bar64@ukr.net.

Musienko Andrii Petrovych - Doctor of Technical Sciences, Associate Professor of the Higher Mathematics Department. Phone: +38(093)7520019. E-mail: mysienkoandrey@gmail.com. 